\title{
Effects of temporary abdominal closure methods on mortality and morbidity in patients with open abdomen
}

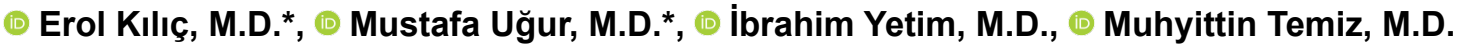

Department of General Surgery, Mustafa Kemal University Faculty of Medicine, Hatay-Turkey

${ }^{*}$ Two authors contributed equally to the work.

\begin{abstract}
BACKGROUND: Open abdomen (OA) in which the abdomen is closed with temporary abdominal closure methods is the most effective in patients who develop severe abdominal sepsis or abdominal compartment syndrome. Major techniques used are VacuumAssisted Closure Method (VACM) and non-vacuum assisted closure method (NVACM). In the present study, the effects of different abdominal closure methods on morbidity and mortality were evaluated.
\end{abstract}

METHODS: In the study, the temporary abdominal closure methods of the patients with OA during 2013-2016 were studied retrospectively. OA etiopathologies, mortality prediction scores, final abdominal closure periods and methods, hospitalization periods, complications (enteroatmospheric fistula, mesh infection, and incisional hernia), and mortality rates of patients who underwent VACM and NVACM were determined and compared.

RESULTS: The present study included 123 patients who underwent VACM $(n=65)$ and NVACM ( $n=58)$. There was no difference between the groups in terms of age, gender, and etiopathogenesis ( $p>0.05)$. The mean APACHE 4 and Multiple Organ Dysfunction Score (MODS) scores in the VACM/NVACM groups in treatment period were $47 / 63$ and II/14, respectively $(p<0.05)$. The mean intensive care and hospitalization periods in the VACM/NVACM groups were II/16 (days) and 22/28 (days), respectively ( $<<0.05$ ). The collection and abscess development rates in the VACM and NVACM groups were $46.2 \%$ and $77.6 \%$, respectively $(p<0.05)$. The rate of enteroatmospheric fistula (EAF) development in the VACM and NVACM groups were $15.4 \%$ and $56.9 \%$, respectively $(p<0.05)$. The mean abdominal closure times in the VACM and NVACM groups were 13 and 17 days, respectively $(p<0.05)$. Mortality rate in the VACM and NVACM groups were $18 \%(n=18)$ and $55 \%(n=32)$, respectively $(p<0.05)$.

CONCLUSION: In patients with OA, the temporary abdominal closure technique VACM has lower complication and mortality rates and shorter hospitalization period than other methods. Therefore, it is an effective and safe method for the treatment of OA.

Keywords: Baker method; Bogota bag; Non-vacuum assisted closure method (NVACM); open abdomen; temporary abdomen closure; acuum-Assisted Closure Method (VACM).

\section{INTRODUCTION}

The aim of open abdomen $(O A)$ is to prevent abdominal sepsis and the development of abdominal compartment syndrome. The fascia or skin of the abdomen is not primarily closed, and the abdomen is left open with various methods and instruments. ${ }^{[1]}$ Abdominal visceral organ edema and complete infection therapy cannot be achieved in patients with severe sepsis originating from abdomen. ${ }^{[2]}$ This can lead to paralytic ileus and intraabdominal hypertension (IAH). Consequently, the patient, who is already in critical condition, can develop multiorgan failure. ${ }^{[3]}$ To prevent the development of such consequences, patients with severe abdominal sepsis and at risk of IAH are commonly treated with OA methods. ${ }^{\left[{ }^{[4}\right]} \mathrm{OA}$ is followed by temporary abdominal closure methods. Various materials and methods like sterile serum packs, aspiration devices, and application of negative pressure are used for this purpose.

Cite this article as: Kılıç E, Uğur M, Yetim İ, Temiz M. Effects of temporary abdominal closure methods on mortality and morbidity in patients with open abdomen. Ulus Travma Acil Cerrahi Derg 2018;24:321-326.

Address for correspondence: Erol Kılıç, M.D.

Mustafa Kemal Üniversitesi Tıp Fakültesi, Genel Cerrahi Anabilim Dalı, Hatay, Turkey

Tel: +90 326 - 2213317 E-mail: ekkilic55@gmail.com

Ulus Travma Acil Cerrahi Derg 2018;24(4):32I-326 DOI: 10.5505/tjtes.2017.95038 Submitted: 09.1I.2017 Accepted: 08.12.2017 Online: 04.04.2018

Copyright 2018 Turkish Association of Trauma and Emergency Surgery 
In the present study, the relation between temporary abdominal closure techniques used in patients with OA after urgent abdominal surgery and their morbidity and mortality was evaluated.

\section{MATERIALS AND METHODS}

Data of the patients with open abdomen after urgent abdominal surgical treatment during 2013-2016 were compiled, and the relation between temporary abdominal closure methods and morbidity and mortality were studied. Furthermore, intensive care unit and in hospital stay duration, peritonitis, collection, abscess, drainage application, and enteroatmospheric fistula (EAF) development were also studied. The patients who died within the first postoperative 24 hours were excluded.

The patients were divided into two groups depending on temporary abdominal closure techniques; vacuum-assisted closure method (VACM) and non-vacuum assisted closure method (NVACM). Demographic features, OA etiopathologies, and mortality prediction scores of the groups were evaluated. They were studied for graft infection and graft excision.

The methods used for final abdominal closure were VACM with mesh, primary fascial closure, planned ventral herniation, and interposition mesh methods, and the differences among the groups were studied.

Acute Physiological and Chronic Health Evaluation (APACHE 4) scores of the patients were estimated on the first day in intensive care unit. The mean APACHE 4, Sequential Organ Failure Assessment (SOFA), Systemic Inflammatory Response Syndrome (SIRS), and Multiple Organ Dysfunction Score (MODS) scores; intensive care unit and in hospital stay duration; and mortality rates were compared. APACHE 4 scores were calculated using https://intensivecarenetwork.com/Calculators/Files/Apache4.html network. ${ }^{[5]}$

Preoperative and postoperative findings of the groups were evaluated for peritonitis, postoperative collection, abscess development, distribution of drainage application, locations and flow rates of EAF, and EAF treatment methods.

In both groups, the patients whose abdominal closures were performed with graft were evaluated for the rates of graft infection and excision (removal) of infected grafts.

\section{Surgical Technique}

On admission, all patients were examined by a general surgeon; all surgeries were performed by a general surgeon. An infectious disease specialist was consulted at admission and in postoperative period, and antibiotic therapy was initiated according to the recommendations.
NVACM group comprised patients who underwent Baker and Bogota bag after OA. In Baker system, lavage was performed with $0.9 \%$ saline and subsequently, OA was closed with sterile vaseline gauze pad and aspirated. In Bogota bag method; as it has been reported in previous studies, necrotic tissues were removed, perforations were repaired, the abdomen was washed and aspirated, drain was placed into the abdomen via laparotomy in the operation room every 48-72 hours, and sterile nutrition or urinary flush bags were attached to the fascia one by one with nonabsorbable suture. ${ }^{[6]}$ In this group, if the fascia of the patient was close enough, the final closure was performed with primary closure, but if the fascia was stretched, onlay nonabsorbable graft was placed on to the fascia, and the fascia was pressed medially in every 3 days. If the fascia could not be closed completely, closure was achieved either by undersizing or by trimming the graft.

In VACM group, (TOPIVAC ${ }^{\circledR}$ ) closed vacuum system was used to assist the postoperative vacuum-assisted closure performance. With the vacuum system, a protective and fluid permeable membrane was laid over the abdominal organs to prevent the adhesion; next, a spongy material allowing fluid absorption was placed over the membrane; finally, whole abdomen was covered with a drape for closure. A 3-cm² opening was left on the drape, and through this opening, 50-150 $\mathrm{mmHg}$ negative pressure was administered with a closedcircuit system continually or at intervals. Second look was performed at 48-72 hours. In this group, after second look, final closure was performed with early primary fascial closure depending on the condition of fascia. If primary fascial closure could not be performed, the same procedure was performed again for 72 hours. After the second 72 hours, primary fascial closure (delayed primary fascial closure) or vacuum-assisted closure and mesh-mediatedfascial closure (VACMM) was performed depending on the condition of fascia. If none of these were possible, it was left for ventral hernia.

VACMM is a vacuum-assisted closure method which is combined with a polypropylene patch. It was performed as described by Petersson et al. ${ }^{[7]}$ On the postoperative sixth day, if the edges of the fascia could not be brought together, a polypropylenepatch was fixed to the edges of fascia and subsequently stretched by performing full-thickness plication. It is plicated over itself in the middle with the help of continuous nonabsorbable suture. In every 3 days, the graft is sutured medially over itself by full-thickness continuous suture to tighten the mesh; therefore, the edges of the fascia are brought closer in the operation room. In patients whose fascia was close enough, the fascia was primarily closed with continuous nonabsorbable sutures or the mesh was undersized and revised to close the abdomen.

\section{Statistical Method}

Data were analyzed using IBM SPSS V23 (Chicago, USA). Compliance of quantitative data with normal distribution was 
assessed using Shapiro-Wilk test. To compare the quantitative data with non-normal distribution, Mann-Whitney $U$ test was used for non-parametric tests. To compare the qualitative data of the groups, Chi-square test was used. Quantitative data with non-normal distribution were presented as median (minimum-maximum). Qualitative data were presented as frequency (percentage). Significance level was taken as $p<0.05$.

\section{RESULTS}

Overall, 123 patients were included in the study (VACM group, $n=65$; NVACM group, $n=58$ ). Those who died within the first postoperative 24 hours were excluded from the study.

There was no statistically significant difference between the groups in terms of age, gender, and etiopathogenesis. The mean APACHE 4 scores in both groups during admission to intensive care unit and in the postoperative period were similar (Table I) ( $>>0.05)$.

The mean APACHE 4 and MODS scores in the VACM/ NVACM groups in treatment period were 47/63 and II/I4, respectively. APACHE 4 and MODS values in the VACM group were lower and statistically significant $(p<0.05)$; however, there was no difference between the groups in terms of SIRS and SOFA scores (Table I) ( $>>0.05)$.

The mean intensive care and hospitalization periods in the VACM/NVACM groups were II/I6 (days) and 22/28 (days), respectively, which were significantly shorter in the VACM group (Table I) $(\mathrm{p}<0.05)$.

Mortality rate in the NVACM group was $55 \%$ and in the VACM group was $18 \%$, and it was statistically significantly lower in the VACM (Table I) $(p<0.05)$.

Peritonitis rate in both groups was $89 \%$ in preoperative period, and there was no statistically significant difference $(p>0.05)$. In the postoperative period, the collection and abscess development rates in the VACM and NVACM groups were $46.2 \%$ and $77.6 \%$, respectively; it was significantly lower in the VACM group $(p<0.05)$. External drainage application for abscess/collection development was $18.5 \%$ in the VACM group and $79.6 \%$ in the NVACM group. Drainage application rate in the VACM group was significantly lower (Table 2) $(p<0.05)$.

Table I. Demographic data, APACHE 4, SOFA, SIRS values, and mortality rates of the groups

\begin{tabular}{|c|c|c|c|}
\hline & VACM $(n=65)$ & $\operatorname{NVACM}(n=58)$ & $\mathbf{p}$ \\
\hline \multicolumn{4}{|l|}{$\operatorname{Sex}(\%)$} \\
\hline Male & $44(68)$ & $37(64)$ & $>0.05^{*}$ \\
\hline Female & $21(32)$ & $21(36)$ & \\
\hline Age (year) & $42(18-85)$ & $40.5(18-76)$ & $0.966^{* *}$ \\
\hline \multicolumn{4}{|l|}{ Primer pathology (\%) } \\
\hline Intestinal perforation & $40(6 I)$ & $36(62)$ & $>0.05^{*}$ \\
\hline Evisceration & $9(14)$ & $9(15.5)$ & \\
\hline Necrotizing pancreatitis & $5(7.7)$ & $5(8.6)$ & \\
\hline Mesenteric ischemia & $2(3.1)$ & $2(3.4)$ & \\
\hline Bile duct injury & $4(6.2)$ & $3(5.2)$ & \\
\hline Liver injury & $5(7.7)$ & $3(5.2)$ & \\
\hline Critical care (day) & II (2-42) & $16(4-31)$ & $0.003^{* *}$ \\
\hline Hospitalization time(day) & $22(3-138)$ & $28(17-94)$ & $0.036^{* *}$ \\
\hline \multicolumn{4}{|l|}{ Mortality predicting Score } \\
\hline Apache $4(/ 286)$ & $75(15-178)$ & $78(21-178)$ & $0.253^{* *}$ \\
\hline SOFA $(0-24)$ & II (2-22) & $13(4-26)$ & $0.102^{* *}$ \\
\hline Sirs/Septic shock (0-5) & $3(0-5)$ & $3(2-5)$ & $0.063^{* *}$ \\
\hline MODS $(0-24)$ & II (2-22) & $14(5-22)$ & $0.045^{* *}$ \\
\hline Apache $4^{\#}(/ 286)$ & $47(11-77)$ & $63(16-88)$ & $0.037^{* *}$ \\
\hline Mortality (\%) & $18(28)$ & $32(55)$ & $0.004^{* *}$ \\
\hline
\end{tabular}


The rate of EAF development was $15.4 \%$ in the VACM group and $56.9 \%$ in the NVACM group. The localization of EAF in small and large intestines was similar in both groups. However, when evaluated for fistula flow rate, EAF flow rate in the VACM group was $<250 \mathrm{ml}$ in $6.2 \%$ patients, $250-500 \mathrm{ml}$ in $3 \%$ patients, and $>500 \mathrm{ml}$ in $6.2 \%$ patients and EAF flow rate in the NVACM group was $<250 \mathrm{ml}$ in $22.4 \%$ patients, $250-500$ $\mathrm{ml}$ in $20.7 \%$ patients, and $>500 \mathrm{ml}$ in $13.8 \%$ patients. Fistula flow rates were significantly lower in the VACM group (Table 2) $(p<0.05)$.

Spontaneous EAF closure rate was 50\% (21\%) higher in the VACM group than in the NVACM group $(p<0.05)$. Surgical closure of EAF was $30 \%$ in the VACM group and $49 \%$ in the NVACM group. Surgical closure of EAF was lower in the VACM group $(p<0.05)$. in the VACM and NVACM groups were $20 \%$ and $30 \%$, respectively, and unclosed EAF rate was higher in the NVACM group (Table 2$)(p<0.05)$.

The mean abdominal closure times in the VACM and NVACM groups were 13 and 17 days, respectively. It was statistically shorter in the VACM group $(p<0.05)$. The methods used for abdominal closure were primary fascial closure, fascial closure with grafting, and planned ventral hernia with skin-only repair. The rates of closure techniques in the VACM and NVACM groups were $31 \%$ and $17 \%$ for primary fascial closure, $38 \%$

Table 2. Complication rate of the groups

\begin{tabular}{|c|c|c|c|}
\hline & VACM $(n=65)$ & NVACM $(n=58)$ & $\mathbf{p}$ \\
\hline Peritonitis preop (\%) & $58(89)$ & $52(89)$ & $>0.05^{*}$ \\
\hline Collection/Abscess (\%) & $30(46.2)$ & $45(77.6)$ & $<0.001^{*}$ \\
\hline Drenage (\%) & $12(18.5)$ & $46(79.3)$ & $<0.001^{*}$ \\
\hline EAF (\%) & $10(15.4)$ & $33(56.9)$ & $<0.001^{*}$ \\
\hline \multicolumn{4}{|l|}{ Fistula localization (\%) } \\
\hline Small bowel & $8(80)$ & $30(90.9)$ & $0.575^{*}$ \\
\hline Colon & $2(20)$ & $3(9.1)$ & \\
\hline \multicolumn{4}{|l|}{$\mathrm{EAF}(\mathrm{ml} / 24 \mathrm{~h})$} \\
\hline Non-fistula & $55(84)$ & $25(43)$ & $<0.00$ I $^{*}$ \\
\hline$<250 \mathrm{ml}$ & $4(6.2)$ & $13(22.4)$ & \\
\hline $250-500 \mathrm{ml}$ & $2(3)$ & $12(20.7)$ & \\
\hline$>500 \mathrm{ml}$ & $4(6.2)$ & $8(13.8)$ & \\
\hline \multicolumn{4}{|l|}{ EAF Closed method (\%) } \\
\hline Spontaneous & $5(50)$ & $7(21)$ & $0.00 I^{*}$ \\
\hline Surgical & $3(30)$ & $16(49)$ & \\
\hline Persistant fistula none-closed & $2(20)$ & $10(30)$ & \\
\hline
\end{tabular}

"Chi-square test; "'Man-Whitney U Test. VACM: Vacuum assisted closure method; NVACM: Non vacuum assisted closure method, EAF: Enteroatmospheric fistula. APACHE 4: Acute Physiological and Chronic Health Evaluation scores; SOFA: Sequential Organ Failure Assessment; SIRS: Systemic Inflammatory Response Syndrome.

Table 3. Abdominal closing time and greft infection/removed rate of grups

\begin{tabular}{lccc}
\hline & VACM (n=65) & NVACM (n=58) & p \\
\hline $\begin{array}{l}\text { Abdominal closed time (day) } \\
\text { Abdominal closure method (\%) }\end{array}$ & $13(3-196)$ & $17(I I-24)$ & $0.01 I^{* *}$ \\
$\quad$ Gm fascial closure & $25(38)$ & $14(24.1)$ & $<0.00 I^{*}$ \\
$\quad$ Primer fascial closure & $20(31)$ & $10(17)$ & \\
$\quad$ Planned ventral hernia & $20(31)$ & $34(59)$ & $0.680^{*}$ \\
Greft infection (\%) & $13(20)$ & $9(15.5)$ & $<0.05^{*}$ \\
Greft removed (\%) & $2(3.1)$ & $9(15.5)$ & \\
\hline "Chi-square test; "Man-Whitney U Test. VACM: Vacuum-assisted closure method; NVACM: Non-vacuum assisted closure \\
method; Gm: Graft mediated.
\end{tabular}


and $24.1 \%$ for fascia-abdomen closure with grafting, and $31 \%$ and $59 \%$ for planned ventral herniation, respectively. While the rates of primary fascial closure and closure with grafting were significantly higher in the VACM group, the rate of planned ventral hernia was higher in the NVACM group (Table 3) $(p<0.05)$.

Infection development rates in the VACM and NVACM groups after grafting were $20 \%$ and $15.5 \%$, respectively $(p>0.05)$, and it was quite similar. The rates of graft excision due to infection in the VACM and NVACM groups were $3.1 \%$ and $15.5 \%$, respectively. In the NVACM group, grafts of all patients who developed graft infection were excised. Graft excision was significantly low in the VACM group (Table 3) $(p<0.05)$.

\section{DISCUSSION}

The main aim of $O A$ is to prevent abdominal sepsis and the development of IAH. Mainly temporary abdominal closure methods used after OA are Bogota bag, Baker, interpositional mesh placement, and VACM. ${ }^{[4,8]}$

The priority in OA treatment is to determine the etiology of peritonitis, drain the intraabdominal fluid, and control the abdominal sepsis source. In patients with severe abdominal sepsis, such as necrotizing soft tissue infections (necrotizing fasciitis), intraabdominal abscess, infected pancreatic necrosis, intestinal infarction, or fecal peritonitis, abdominal visceral organ edema treatment and complete infection eradication cannot be achieved; OA is employed in them. Recently, it has become the standard procedure in the treatment of patients with diffuse peritonitis who are in need of urgent abdominal surgery. ${ }^{[2,3,9]}$ The diagnoses of patients who were treated with $\mathrm{OA}$ in our study were consistent with those in the literature.

Various temporary and final abdominal closure methods have been described for patients with OA. Methods such as skinonly closure, closure with sterilized urinary irrigation or parenteral nutrition bags (Bogota bag), closure with absorbable/ nonabsorbable meshes, negative pressure wound therapy, or Wittmann patch technique can be used. ${ }^{[10,11]}$ The ideal procedure in patients with $\mathrm{OA}$ is to perform the final abdominal closure within the first 10 days either with direct fascial closure or biologic/synthetic mesh. ${ }^{[12,13]}$ If closure could not be achieved in early days, ventral incisional hernia developed due to the lateral retraction of fascia edges. Moreover, both hospitalization period and morbidity and mortality increase because of adhesions. ${ }^{[14]}$ Vacuum methods used in OA wounds eliminate the necessity of fascial closure. The mechanical effect they generate causes the wound edges and the oblique muscles to come closer to the midline. This effect also helps the fascial primary closure occur in higher rates. ${ }^{[5,15]}$ In our study, the rates of primary fascial closure and fascial-abdominal closure with graft were found to be higher in the VACM group than in the NVACM group, which is consistent with the literature.
In patients with OA major complications, such as multiple organ dysfunction $(30 \%-40 \%)$, enterocutaneous fistula (2\%$25 \%$ ), intraabdominal bacterial colonization (83\%), and ventral hernia (25\%), are encountered. The mortality rate of patients with OA with intraabdominal infection is higher than that of the patients with trauma, and patients with infected OA have a mortality rate that reaches up to $50 \%$. If the intraabdominal infection cannot be completely eradicated, paralytic ileus develops, which leads to intraabdominal tension, fluid collection, and intraabdominal hypertension (IAH). IAH negatively affects various systems and organs, particularly cardiovascular and renal systems. Consequently, the patient who is already in critical condition, may develop multiorgan failure..$^{[3,16-18]}$

The advantages of VACM method over NVACM methods are as follows: increase in the blood flow at the wound site by decreasing the interstitial pressure and reduction in the severity of inflammation and infection by removing the exudate. Furthermore, it increases angiogenesis and granulation by stimulating the cell reproduction and proliferation, thereby positively contributing to wound healing. Its disadvantages are as follows: it is expensive, it may cause pain and bleeding due to continuous negative pressure, and it may occasionally lead to toxic shock syndrome and thrombosis. ${ }^{[5]}$

In the present study, EAF, multiple organ dysfunction, and mortality were significantly lower and intensive care unit and in hospital stay duration were shorter in the VACM group than in the NVACM group. In addition, mesh infections were encountered less frequently in the VACM group. EAF flow rate was lower and spontaneous closure rate was higher in the VACM group. Therefore, we believe that VACM achieves these effects by removing exudate and inflammatory mediators at the site. ${ }^{[19]}$

VACM decreases the mortality, morbidity, and complication rates in patients with $\mathrm{OA}$. It also positively contributes to the final abdominal closure in the early period, thereby shortening the intensive care unit and in hospital stay duration. Because of these positive effects, it is an effective and safe method in OA treatment.

No funding has been provided for this work.

Conflict of interest: None declared.

\section{REFERENCES}

1. Coccolini F, Biff W, Catena F, Ceresoli M, Chiara O, Cimbanassi S, et al. The open abdomen, indications, management and definitive closure. World J Emerg Surg 2015;10:32. [CrossRef]

2. Borraez AO. Abdomen abierto: la herida más desafiante. Rev Colomb Cir 2008;23:204-9.

3. Nathens AB, Brenneman FD, Boulanger BR. The abdominal compartment syndrome. Can J 1997;40:254-8.

4. Atema JJ, Gans SL, Boermeester MA. Systematic review and meta-analy- 
sis of the open abdomen and temporary abdominal closure techniques in non-trauma patients. World J Surg 2015;39:912-25. [CrossRef]

5. Apache IV Score-Intensive Care Network. http://intensivecarenetwork. com/Calculators/Files/Apache4.html

6. Ribeiro Junior MA, Barros EA, de Carvalho SM, Nascimento VP, Cruvinel Neto J, Fonseca AZ. Open abdomen in gastrointestinal surgery: Which technique is the best for temporary closure during damage control? World J Gastrointest Surg 2016; 27;8:590-7. [CrossRef]

7. Petersson U, Acosta S, Björck M. Vacuum-assisted wound closure and mesh-mediated fascial traction-a novel technique for late closure of the open abdomen. World J Surg 2007;31:2133-7. [CrossRef]

8. Willms A, Güsgen C, Schaaf S, Bieler D, von Websky M, Schwab R. Management of the open abdomen using vacuum-assisted wound closure and mesh-mediated fascial traction. Langenbecks Arch Surg 2015;400:91-9. [CrossRef]

9. Sartelli M, Abu-Zidan FM, Ansaloni L, Bala M, Beltrán MA, Biffl WL, et al. The role of the open abdomen procedure in managing severe abdominal sepsis: WSES position paper. World J Emerg Surg 2015;10:35:1-11.

10. Stawicki SP, Cipolla J, Bria C. Comparison of open abdomens in nontrauma and trauma patients: A retrospective study. OPUS 12 Scientist 2007;1:1-8.

11. Tieu BH, Cho SD, Luem N, Riha G, Mayberry J, Schreiber MA. The use of the Wittmann Patch facilitates a high rate of fascial closure in severely injured trauma patients and critically ill emergency surgery patients. J Trauma 2008;65:865-70. [CrossRef]

12. López-Cano M, Pereira JA, Armengol-Carrasco M. "Acute postoperative open abdominal wall": nosological concept and treatment implications. World J Gastrointest Surg 2013;5:314-20. [CrossRef]

13. Regner JL, Kobayashi L, Coimbra R. Surgical strategies for management of the open abdomen. World J Surg 2012;36:497-10. [CrossRef]

14. Refinetti RA, Martinez R. Pancreatite necro-hemorrágica: atualização e momento de operar. ABCD. ABCD, Arq Bras Cir Dig 2010;23:122-7.

15. Boele van Hensbroek P, Wind J, Dijkgraaf MG, Busch OR, Goslings JC. Temporary closure of the open abdomen: a systematic review on delayed primary fascial closure in patients with an open abdomen. World J Surg 2009;33:199-207. [CrossRef]

16. Balogh Z, McKinley BA, Holcomb JB, Miller CC, Cocanour CS, Kozar RA, et al. Both primary and secondary abdominal compartment syndrome can be predicted early and are harbingers of multiple organ failure. J Trauma 2003;54:848-61. [CrossRef]

17. Perez D, Wildi S, Demartines N, Bramkamp M, Koehler C, Clavien PA. Prospective evaluation of vacuum-assisted closure in abdominal compartment syndrome and severe abdominal sepsis. J Am Coll Surg 2007;205:586-92. [CrossRef]

18. Nicholas JM, Rix EP, Easley KA, Feliciano DV, Cava RA, Ingram WL, et al. Changing patterns in the management of penetrating abdominal trauma: the more things change, the more they stay the same. J Trauma 2003;55:1095-110. [CrossRef]

19. Plaudis H, Rudzats A, Melberga L, Kazaka I, Suba O, Pupelis G. Abdominal negative-pressure therapy: a new method in countering abdominal compartment and peritonitis - prospective study and critical review of literature. Ann Intensive Care 2012;20 Suppl 1:S23. [CrossRef]

\section{ORIJINAL ÇALIŞMA - ÖZET}

\section{Açık karın (open abdomen) uygulanan hastalarda geçici karın kapama yöntemlerinin mortalite ve morbidite üzerine etkisi}

\section{Dr. Erol Kılıç, Dr. Mustafa Uğur, Dr. İbrahim Yetim, Dr. Muhyittin Temiz}

Mustafa Kemal Üniversitesi Tıp Fakültesi, Genel Cerrahi Anabilim Dalı, Hatay

AMAÇ: Ciddi abdominal sepsis ve abdominal kompartman sendromu gelişen hastalarda günümüzde uygulanan en önemli tedavi yöntemi abdomenin geçici karın kapama yöntemleri ile kapatılı̆̆ı açık karın (AK) uygulamasıdır. Bu amaçla kullanılan başlıca yöntemler Vacum Asisted Closure Method (VACM) ve non-vacum asisted closure (NVACM) teknikleridir. Bu çalışmada farklı karın kapama yöntemlerinin morbidite ve mortalite üzerine olan etkileri incelendi.

GEREÇ VE YÖNTEM: Çalışmada 2013-2016 yılları arasında AK uygulanan hastaların geçici karın kapama yöntemleri geriye dönük olarak incelendi. VACM ile NVACM uygulanan hastaların AK etiyopatolojisi, mortalite tahmin skorları, nihai karın kapama süresi ve yöntemleri, hastanede yatış süresi, gelişen komplikasyon (enteroatmosferik fistül, mesh enfeksiyonu, insizyonel herni) ve mortalite oranları belirlenerek karşılaştırıldı.

BULGULAR: Bu çalışmaya VACM $(n=65)$ ve NVACM $(n=58)$ uygulanan 123 hasta dahil edildi. Grupların (VACM ve NVACM) yaş, cinsiyet ve etiyopatogenezleri arasında fark yoktu ( $p>0.05$ ). Tedavi döneminde ortalama APACHE 4 ve MODS skorları sırasıyla 47/63 ve II//4'tü ( $p<0.05$ ). Grupların yoğun bakım ünitesi ve hastanede ortalama yatış süreleri sırasıyla II / I6 ve $22 / 28$ gündü $(p<0.05)$. Apse, koleksiyon gelişme oranı sırasıyla \%46.2 ve \%77.6 idi $(p<0.05)$. Enteroatmosferik fistül gelişme oranı sırasıyla \% I5.4 ve \%56.9'du. Ortalama karın kapama zamanı sırasıyla I3 ve 17 gündü $(p<0.05)$. VACM grubunda $18(\% 28)$, NVACM grubunda $32(\% 55)$ hasta kaybedildi $(p<0.05)$.

TARTIŞMA: Açık karın uygulanan hastalarda geçici karın kapama yöntemi olan VACM diğer yöntemlere göre daha düşük komplikasyon ve mortalite oranına sahiptir. Ayrıca hastanede yatış süresi daha kısadır. Açık karın tedavisinde etkili ve güvenli bir uygulama yöntemidir.

Anahtar sözcükler: Baker yöntemi; Bogota-bag; geçici karın kapama yöntemleri; non-vacuum assisted closure (NVACM); open abdomen; Vacuum Assisted Closure Method (VACM).

Ulus Travma Acil Cerrahi Derg 2018;24(4):321-326 doi: 10.5505/tites.2017.95038 